\title{
Analysis on Pronunciation Errors Made By First Semester Students of English Department STKIP CBN
}

\author{
Agnes Maria Diana Rafael \\ Dosen STKIP Citra Bina Nusantara \\ Jln. Manafe, No. 17, Kayu Putih Oebobo, Kupang-NTT \\ rafaelagnesmariadiana@gmail.com
}

\begin{abstract}
This study is conducted find out the pronunciation errors made by the first semester students of English Education Department in STKIP CBN. In conducting the data, the researcher gave the pre-test to the informants, then; the researcher recorded the performances and transcribed the data. The secondary data was gathered from the interview. Based on the data analysis, there are nine types of errors pronunciation made by the subjects. The first error is the subjects substituted a vowel /ce/ and six consonants /kj/,/tfl//fl//dz/ and /3/ with Indonesian sounds. The second error is the subjects substituted some English vowels into Indonesian vowel. The third error is cognates word cases. The fourth is language interference. The fifth is pronouncing the silent consonant $\mathrm{h} /$. The sixth error is deleting or omitting some consonants that appeared at the end of some English words. The seventh error is the subjects pronounced the silent consonant /t/ in the word "often". The eighth error is the subjects added the consonant / $r /$ at the word that word doesn't required the consonant /r/. The last error is some subjects seemed to generalize the pronunciation of the past tense morpheme which is ended by a bound morpheme /ed/. There are three causes of students' pronunciation error made in speaking English. The first is an interference error, the second is an intra-lingual errors and the last is a developmental error.
\end{abstract}

Keywords: Error, Pronunciation, Language Interference, Cognate

\begin{abstract}
Abstrak : Penelitian ini dilakukan untuk mengetahui kesalahan pengucapan yang dilakukan oleh mahasiswa semester pertama Departemen Pendidikan Bahasa Inggris di STKIP CBN. Dalam melakukan data, peneliti memberikan pre-test kepada informan, kemudian; peneliti mencatat pertunjukan dan menyalin data. Data sekunder dikumpulkan dari wawancara. Berdasarkan analisis data, ada sembilan jenis kesalahan pengucapan yang dilakukan oleh subjek. Kesalahan pertama adalah subyek mengganti vokal / a / dan enam konsonan / kj /, / t / / / / / / 3 / dan / 3 / dengan suara Indonesia. Kesalahan kedua adalah subyek mengganti beberapa vokal bahasa Inggris menjadi vokal bahasa Indonesia. Kesalahan ketiga adalah kasus kata-kata serumpun. Yang keempat adalah gangguan bahasa. Yang kelima adalah mengucapkan konsonan diam / $h$ /. Kesalahan keenam adalah Menghapus atau menghilangkan beberapa konsonan yang muncul di akhir beberapa kata bahasa Inggris. Kesalahan ketujuh adalah subyek diucapkan konsonan diam I $t$ / dalam kata "sering". Kesalahan kedelapan adalah subjek menambahkan konsonan / $r$ / pada kata yang kata tidak memerlukan konsonan / $r$ /. Kesalahan terakhir adalah beberapa subjek tampak menggeneralisasi pengucapan morfem past tense yang diakhiri dengan morfem terikat / ed \% Terdapat tiga penyebab kesalahan pengucapan siswa yang dibuat dalam berbicara bahasa Inggris, yaitu pertama adalah kesalahan interferensi, yang kedua adalah kesalahan intra-bahasa dan yang terakhir adalah kesalahan perkembangan.
\end{abstract}

Kata kunci: Kesalahan, Pengucapan, Gangguan bahasa, Serumpun

\section{PENDAHULUAN}

Speaking is one of the English skills that is very crucial to be learned by the non-native learners, especially in Kupang, East Nusa
Tenggara (ENT) Province. In ENT Province, as well as in Indonesia, English is treated as a foreign language, as the result; if we want to master this language we should learn it continuously. Even though, English is treated as 
the foreign language in this country, but as the Indonesian citizen who live in the globalization and digital era, the university students have to master that language, so they could face the free market challenged. However, one of the problems faces by the students in Kupang in learning English is the difficulties in pronouncing English words correctly and accurately. For Kupang's Students, English is the first foreign language that they learn, whether they learn it in the formal education or nonformal education. Unfortunately, after learning it for several hours in a week, they only communicate used it in the specific condition and situation. The students rarely use English in their daily conversation. Therefore, it is understandable if the students will produce a lot of errors in their pronunciation.

Dalton, (1998), stated that the students must be aware of pronunciation elements. English pronunciation is one of the most important sub-skills in speaking skill. Speaking without considering the pronunciation will cause different interpretation in meaning among the speakers and listeners. There are many misunderstanding in the meaning of the words spoken caused by the inaccurately and wrongly pronunciation. Unfortunately, the sound system in each English word is different from one word to another word; these things cause difficulties in reciting and pronouncing the English words for most of Indonesian people, involve the students in Kupang city. Morley (1991), cited in Armington (1994, p. 27), support Pica's statement by saying, "Intelligible pronunciation is an essential component of communicative competence" (p. 488). In accordance to that,
MacCarty (1978) points out that people judge the other people through how perfect they utter the language, and how the language is sounded to their ears. This points to the importance of pronunciation since what we pronounce reflects the meaning of the word and reflect our selfcompetence in mastering the language.

Pronunciation itself includes features such as stress, rhythm and intonation (aspects of prosody). These features need to be taken into account when it comes to looking at the learning outcome. David Nunan, (1999, p. 105), suggests that the best time for students to learn a language in order to become as native-like in their pronunciation as possible is before the onset of puberty. This is because the mother tongue has less influence on pronunciation at this stage. When it comes to vocabulary and grammar, a student's first language is less apparent than in pronunciation. By learning the pronunciation since the early age the students can produce the English words accurately. However, English subject is not the main subject that has been learned by the ENT's students in the primary level, the students learned English when they became the Junior School students. Therefore, they have a very limited times in learning that language, so the errors and the mistake in pronouncing the English words are unavoidable. Although mistakes and errors are two different words with different meaning. Brown (1980, p. 165) stated that a mistake refers to performance errors that is either random on a slip of the tongue, in that it is failure to utilize a known system correctly. The same opinion had also said Arjati (2007), she claimed that the speakers are normally capable of recognizing and correcting 
their mistake. It means that when the learners produce mistake they can make self-corrections, but if they make errors they cannot correct themselves. The English teachers must explain the errors that the learners did, because it is related to their intralangue. Besides that, the errors actually are the part of learning process

English learners in Kupang are tend to commit more errors in pronouncing the English words because when they produce the spontaneous speech, they have limited time to think and to correct the errors in their speech. Moreover, many students in Kupang are come from many districts in ENT Province. Those students have their own native languages, which might influence in the English pronunciation. This is due to the distinction of vowel and consonant sounds among the native languages and English (Wan, p. 2017). Dulay, Burt \& Krashen, (1982), added that in learning English, mostly of the native speakers tend to make errors. They claimed that an error in the acquiring process is unavoidable and making errors is part of learning.

In fact, many students in Kupang cannot produce the English words correctly. Even the English Department students, who study English almost every day, make a lot of error in pronouncing the English words. The crucial thing is those students are expected to be the English teachers after finishing their study in English Education Department of STKIP CBN. Therefore, they have to be able to train themselves to pronounce the exact English words, no matter what will happen to them. There is a great expectation from all the people to them. Their English competency in mastering the right pronunciation will determine how proficient they are to be the English teachers in the future. Of course there are many factors that cause the mispronouncing that have been committed by them. Hence, this view challenged the researcher to conduct a research to reveal the kind of errors that occurs in the first semester students' English pronunciation, because the writer realized that the accurately pronunciation is very crucial to support the student's future profession and for further education in abroad.

In the following are provided some previous studies that the writer used in order to support this new current research. The first previous study is a thesis conducted by Kartyastuty (2017). In her research she analyzed about the error pronunciation of English vowels of the first semester students of English education department in IAIN Surakarta. She conducted the research in order to identify errors in pronouncing English vowels and to classify the errors by its types. Her research is used the descriptive qualitative method. The result showed that the participants performed three types of pronunciation errors, those are substitution, insertion and omission.

The next study that the research used as the literature review for encouraging the writer's research has been done by Riyani and Prayogo (2015). They analyzed about the pronunciation errors made by Indonesian singers in Malang in singing the English songs. In collecting the data, they used the recorded material of the live performances of the singers, found the errors, and analyzed them. The researcher counted that there are 506 pronunciation errors out of the 2,569 words (19.69\%) made by the Indonesian 
singers in singing the English songs. It was revealed that there were three kinds of pronunciation errors. It was found that there were 226 errors in consonant pronunciation made by the singers $(44.66 \%)$. It was also found that there were 186 vowel errors $(36.76 \%)$, and the last were 94 diphthong errors $(18.58 \%)$.Finally, this research is expected to be able to help the Indonesian singers in Malang to improve their pronunciations, to the students and also lecturers to make this study as a reference in mastering the basic knowledge of phonology.

The last research was conducted by Islamiyah (2012); she studied about the error on English sound produced by English learners. In her research she used mix method. She began with the qualitative and then in order to know the percentage of each data, she applied the quantitative one. The results of her study revealed that most of the students made some errors in pronouncing English sounds which they cannot found in their first language such as the sound $/ æ /, / \int /, / \theta /, / ð /$, and $/ 3 /$.

The research realized that the study about the error pronunciation is very important to be done in order to investigate the student's problem. By finding the result, hopefully the students and the lecturer can improve their teaching and learning method and strategy in order to minimize the errors in pronouncing the English words. Therefore, the research interests to analyze the error pronunciation made by the first semester students of English Department at STKIP CBN.

\section{METODOLOGI PENELITIAN}

In conducting to this research, the researcher uses descriptive qualitative research. The subjects were eleven students at first semester of English Education Department of STKIP CBN in academic year 2018/2019. In this research, the researcher collected the data from the subjects. The recorded tape performance is the main data, and then the researcher transcribed the data in order to simplify the data analysis.

The main data for this research were gathered through following procedures. First, the researcher gave the pre-test to the informants by asking them to read aloud the lists of English words, then; the researcher recorded their performances and transcribed the data. The second step is the researcher gave them the first treatment. In the first treatment, the researcher played a video that showed how an English native speaker pronounced and read that list as the real models. By showing them the video, the researcher expected that those informants could imitate and produce the correct pronunciation. The last step is the researcher distributed again the list of words and asked the subjects to read it aloud.

The second treatment was given by repeating exactly the same step as the previous treatment. The subjects were asked to pronounce the list of words and to read aloud the reading text. In this case the list of words was ordered randomly. The aim of the second post-test was to recheck and evaluate whether their pronunciations changed and improved as the result of imitating the native speakers in the video or not.

The performance of the subjects was audiorecorded, and then the researcher made a 
transcription. After making the transcription, the researcher identified the errors. In identifying the errors, the researcher used Oxford Dictionary as the main source for English standard pronunciation. After identifying the errors, the final step is the researcher described it adequately.

The secondary data was gathered from the interview. In interview, the researcher gave some questions to the subjects in order to find out the causes of errors pronunciation made by them. The questions are the open questions; the questions that the researchers delivered to the subjects are based on the errors that they made.

\section{RESULT}

The researcher took the data from eleven students as the subjects. They are eleven students of the first semester of English Education Department at STKIP CBN. They speak their own mother languages (Kupang Malay, Tetun language, Helong Language, Dawan Amarasi Language, Rote Language and Lembata) as the first language, then they speak Indonesian as the second language, and now they are learning English as a foreign language. This research has two aims; the first aim is to find out the pronunciation errors made by the first semester students, who are learning English in purposing to become English teachers, in producing English sounds. The second aim is to find out the causes of the errors pronunciation made by the students. In order to answer those questions, the researcher applied three instruments: a list of words where the students are being asked to pronounce the words, the second instrument is a recording and the last instrument is the interview. The researcher reports and describes the data findings as follows: 
Tabel 1 : Errors Pronunciation Data

\begin{tabular}{|c|c|c|c|c|c|}
\hline \multicolumn{6}{|c|}{ ERRORS PRONUNCIATION } \\
\hline \multirow[t]{2}{*}{ No } & \multirow[t]{2}{*}{ Words } & \multicolumn{2}{|c|}{ Transcription } & Subjects & Description of Pronunciation Errors \\
\hline & & $\begin{array}{c}\text { Dictionar } \\
\text { y } \\
\text { Transcrip } \\
\text { tion }\end{array}$ & $\begin{array}{c}\text { As } \\
\text { Recorded }\end{array}$ & & \\
\hline 1 & Apple & /'æpl/ & $\begin{array}{l}\text { /'eipəl/ } \\
\text { /apél/ }\end{array}$ & $\begin{array}{l}2,3,4,7,11 \\
6\end{array}$ & $\begin{array}{l}\text { Substitute the vowel /a/ into the } \\
\text { diphthong /ei/ } \\
\text { Cognate }\end{array}$ \\
\hline 2 & Accurate & /'ækjərət/ & /aku·rat/ & $1,5,7,10$ & $\begin{array}{l}\text { Substitute the diphthong/æ/ into } \\
\text { vowel /e/, the deletion of consonant } \\
\text { cluster sound /kj/ into a single } \\
\text { consonant /k/ and substitute the } \\
\text { vowel /e/ into vowel /ð/ } \\
\text { Cognates }\end{array}$ \\
\hline 3 & Achieve & /o'tfi:v/ & /a'si:v/ & $1,2,3,5,7,8$ & $\begin{array}{l}\text { Substitute the sounds } / \mathrm{t} / \text { that do not } \\
\text { exist in Indonesian with the sound } / \mathrm{s} /\end{array}$ \\
\hline 4 & Animal & /'ænıml/ & /'animol/ & $1,2,3,4,6,10$ & Interference of Indonesian \\
\hline 5 & Ant & /ænt/ & /ent/ & $\begin{array}{l}1,2,3,4,5,6,7,1 \\
0\end{array}$ & $\begin{array}{l}\text { Interference of Indonesian by } \\
\text { changing the diphthong /æ/ with the } \\
\text { vowel /e/ }\end{array}$ \\
\hline 6 & $\begin{array}{l}\text { Annivers } \\
\text { ary }\end{array}$ & $\begin{array}{l}\text { /,æni'v3: } \\
\text { səri/ }\end{array}$ & $\begin{array}{l}\text { /, eni'v3:sə } \\
\text { ri/ }\end{array}$ & $3,4,7$ & $\begin{array}{l}\text { Substitute the vowel /æ/ with vowel } \\
\text { /e/ }\end{array}$ \\
\hline 7 & $\begin{array}{l}\text { Appreciat } \\
\mathrm{e}\end{array}$ & $\begin{array}{l}\text { /a'pri:fiei } \\
\text { t/ }\end{array}$ & /a'pri:sieIt & $1,2,3,5,7,8$ & $\begin{array}{l}\text { Substitute the sound } / \mathrm{J} / \text { with } \\
\text { consonant } / \mathrm{s} /\end{array}$ \\
\hline 8 & Baked & /'berkt/ & $\begin{array}{l}\text { /'bekt/ } \\
\text { /beked/ }\end{array}$ & $\begin{array}{l}1,3,5 \\
2,4,6,7,8,11\end{array}$ & $\begin{array}{l}\text { The deletion of vowel /i/ } \\
\text { Generalization }\end{array}$ \\
\hline 9 & Believe & /bi'li:v/ & /be'li:v/ & $1,2,3,4,7,8,11$ & $\begin{array}{l}\text { Substitute the vowel/I/ with vowel } \\
\text { /e/ and there is no stress at the } \\
\text { second syllables }\end{array}$ \\
\hline
\end{tabular}




\begin{tabular}{|c|c|c|c|c|c|}
\hline 10 & Bury & /beri/ & /buri/ & $\begin{array}{l}1,2,3,4,5,6,7,8 \\
, 9,10,11\end{array}$ & Intralingua interference \\
\hline 11 & Bought & /bo:t/ & /baut/ & $1,2,3,6,7$ & Intralingua interference \\
\hline 12 & Brought & /bro:t/ & /brau:t/ & $1,2,3,4,6,7$ & Intralingua interference \\
\hline 13 & $\begin{array}{l}\text { Challeng } \\
\text { e }\end{array}$ & $\begin{array}{l}/ \operatorname{tg} \operatorname{al} \ln (\mathrm{d}) \\
3 /\end{array}$ & /'celen/ & 4,5 & $\begin{array}{l}\text { Substitute the sounds } / \mathrm{t} / \text { that do not } \\
\text { exist in Indonesian with the } \\
\text { consonant /c/ and pronounce the } \\
\text { word as it is (intralingua } \\
\text { interference) }\end{array}$ \\
\hline 14 & Called & /ko:ld/ & / ka:ld/ & $2,4,6,8,11$ & $\begin{array}{l}\text { Substitute the vowel /o/ with the } \\
\text { vowel /a/ }\end{array}$ \\
\hline & & & $\begin{array}{l}\text { / ko:1/ } \\
\text { //ko:ldid/ }\end{array}$ & $\begin{array}{l}1,5,7,9,10 \\
3\end{array}$ & $\begin{array}{l}\text { Deleting the consonant cluster /ld/ } \\
\text { Generalization }\end{array}$ \\
\hline 15 & Crash & $/ \mathrm{kra} /$ & $/ \mathrm{kras} /$ & $4,6,8$ & $\begin{array}{l}\text { Substitute the sound } / \mathrm{J} / \text { with } \\
\text { consonant } / \mathrm{s} /\end{array}$ \\
\hline 16 & Cooked & /kukt/ & $\begin{array}{l}\text { /kuk/ } \\
\text { /kuked/ }\end{array}$ & $\begin{array}{l}1,4,5,6,7,9,10 \\
2,3,8,11\end{array}$ & $\begin{array}{l}\text { Deleting the consonant cluster } \\
\text { Generalization }\end{array}$ \\
\hline 17 & Climbed & /k1 1 Imd/ & /kleim/ & $\begin{array}{l}1,2,3,4,6,7 \\
11\end{array}$ & $\begin{array}{l}\text { Substitute the diphthong } / \Lambda \mathrm{I} / \text { with the } \\
\text { diphthong /eI/ } \\
\text { Generalization }\end{array}$ \\
\hline 18 & Divided & $\begin{array}{l}/ \text { dI }{ }^{\prime} \text { v IIdI } \\
\text { d/ }\end{array}$ & /di'v vid/ & $1,2,3,4,6,7,10$ & Deleting the past tense sound /Id/ \\
\hline 19 & Data & /'deita/ & /data/ & $1,5,6,9$ & Cognates \\
\hline 20 & Double & $/ / \mathrm{d} \Lambda \mathrm{b}(ə) \mathrm{l} /$ & /'dobəl & $1,3,4,6,8$ & $\begin{array}{l}\text { Substitute the vowel / } / \text { with the } \\
\text { vowel /o/ }\end{array}$ \\
\hline 21 & Decided & $/ / \mathrm{dI}^{\prime} \mathrm{s} \Lambda \mathrm{I} \mathrm{dI} \mathrm{d}$ & /de's $\Lambda$ IdId/ & $1,4,5,6,7,9,10$ & $\begin{array}{l}\text { Substitute the vowel /I/ with the } \\
\text { vowel /e/ }\end{array}$ \\
\hline 22 & Dead & $/ \mathrm{d} \varepsilon \mathrm{d} /$ & $/ \mathrm{dad} /$ & 5 & $\begin{array}{l}\text { Substitute the vowel / } / \text { / with the the } \\
\text { vowel /a/ }\end{array}$ \\
\hline 23 & Envelope & $\begin{array}{l}\text { /'Envaləu } \\
\mathrm{p} /\end{array}$ & /'Envoloup & $2,3,5,8$ & $\begin{array}{l}\text { Substitute the second vowel / } / \text { with } \\
\text { the vowel } / \mathrm{\jmath} /\end{array}$ \\
\hline & & & /'Envələp/ & $1,4,6,9,11$ & 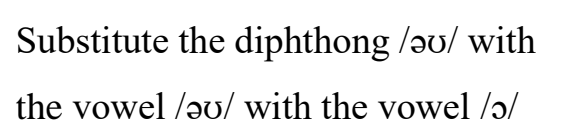 \\
\hline
\end{tabular}




\begin{tabular}{|c|c|c|c|c|c|}
\hline 24 & Fur & $/ \mathrm{f} 3:(\mathrm{r}) /$ & /fu:(r)/ & $2,5,7,10$ & $\begin{array}{l}\text { Substitute the vowel /3/ with the } \\
\text { vowel /u/ and } \\
\text { pronouncing it as it is, intralingua } \\
\text { interference }\end{array}$ \\
\hline 25 & Final & /'f $\mathrm{A} \operatorname{In}(\partial) 1 /$ & /' final/ & $1,3,4,6,7,8$ & Cognates \\
\hline 26 & Find & /f $\Lambda$ Ind/ & /find/ & $5,7,9$ & $\begin{array}{l}\text { Substitute the vowel } / \Lambda / \text { and the } \\
\text { vowel /I/ with the vowel /I/ }\end{array}$ \\
\hline 27 & Forgot & /fə' got/ & /for'gpt/ & $1,2,5,9$ & $\begin{array}{l}\text { Substitute the vowel /a/ with the } \\
\text { vowel / } / \text { / and adding the consonant } \\
\text { /r/ (pronouncing the word as it is) }\end{array}$ \\
\hline 28 & Great & /grett/ & /grit/ & $1,8,9$ & $\begin{array}{l}\text { Substitute the diphthong /eI/ with the } \\
\text { vowel /I/ }\end{array}$ \\
\hline 29 & Husband & $\begin{array}{l}\text { /'huzbən } \\
\text { d/ }\end{array}$ & /'husbənd/ & $1,5,8$ & $\begin{array}{l}\text { Substitute the vowel / } / \text { with the } \\
\text { vowel /u/ and substitute the } \\
\text { consonant /z/ with the consonant /s/ }\end{array}$ \\
\hline 30 & $\begin{array}{l}\text { Increasin } \\
\text { gly }\end{array}$ & $\begin{array}{l}\text { /In'kri:si } \\
\text { yli/ }\end{array}$ & $\begin{array}{l}\text { /In'kre:sin } \\
\text { li/ }\end{array}$ & $1,2,5,6,9$ & $\begin{array}{l}\text { Substitute the second vowel /i/ with } \\
\text { the vowel /e/ }\end{array}$ \\
\hline 31 & Musician & $\begin{array}{l}\text { /mju:'zIJ( } \\
\text { ə)n }\end{array}$ & $/$ /mu: 'sisan & 1,5 & $\begin{array}{l}\text { Substitute the consonant cluster /mj/ } \\
\text { with the single consonant /m/, } \\
\text { substitute the consonant /z/ with the } \\
\text { consonant /s/, substitute the } \\
\text { consonant / } / \text { / with consonant /s/ and } \\
\text { substitute the vowel /(ə)/ with the } \\
\text { vowel /a/ }\end{array}$ \\
\hline & & & $\begin{array}{l}\text { /mu: 'sIs } \\
\text { (ə)n/ }\end{array}$ & $3,4,9$ & $\begin{array}{l}\text { Substitute the consonant cluster /mj/ } \\
\text { with the single consonant } / \mathrm{m} / \text {, } \\
\text { substitute the consonant /z/ with the } \\
\text { consonant /s/ and substitute the } \\
\text { consonant / } / \text { with consonant } / \mathrm{s} /\end{array}$ \\
\hline 32 & Measure & /'mezə/ & /'mesur/ & $1,2,4,5,6,7,8,9$ & $\begin{array}{l}\text { Substitute the consonant / } / \text { with the } \\
\text { consonant /s/, substitute the vowel } \\
\text { /a/ with the vowel /u/ and adding the } \\
\text { consonant /r/ }\end{array}$ \\
\hline 33 & Played & /pleid/ & $\begin{array}{l}\text { /plei/ } \\
\text { /pleyid/ }\end{array}$ & $\begin{array}{l}1,5,8 \\
2,3,4,6,7\end{array}$ & $\begin{array}{l}\text { Omitting the consonant } / \mathrm{d} / \\
\text { Generalization }\end{array}$ \\
\hline
\end{tabular}




\begin{tabular}{|c|c|c|c|c|c|}
\hline 34 & Pushed & $/ \mathrm{pvg} /$ & $\begin{array}{l}\text { /pus/ } \\
\text { /pushed/ }\end{array}$ & $\begin{array}{l}1,2,3,5 \\
4,6,9\end{array}$ & $\begin{array}{l}\text { Substitute the consonant /J/ with the } \\
\text { consonant /s/ } \\
\text { Generalization }\end{array}$ \\
\hline 35 & Pressure & /'prefə/ & /'presər/ & $1,3,5,8,9$ & $\begin{array}{l}\text { Substitute the sound } / \delta / \text { that do not } \\
\text { exist in Indonesia }\end{array}$ \\
\hline 36 & Often & /'o:fn/ & /'o:ftən/ & $\begin{array}{l}1,2,3,4,5,6,7,8 \\
, 9,10,11\end{array}$ & $\begin{array}{l}\text { Pronouncing the silent consonant } / \mathrm{t} / \\
\text { and silent vowel /a/ }\end{array}$ \\
\hline 37 & Washing & /'wofin/ & /'wosin/ & $1,2,5,8,9$ & $\begin{array}{l}\text { Substitute the sounds that do not } \\
\text { exist in Indonesian }\end{array}$ \\
\hline 38 & $\begin{array}{l}\text { Wonderf } \\
\text { ul }\end{array}$ & 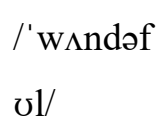 & 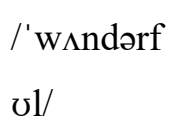 & $1,5,8$ & The addition of consonant $/ \mathrm{r} /$ \\
\hline
\end{tabular}


The following section below presents the discussion of the analysis of the types of pronunciation errors made by the subjects and the discussion about the causes of errors. There nine types of errors pronunciation made by the subjects. Here are the discussions of seven types of errors pronunciation.

The first error is the subjects substituted eight English sounds that do not exist in Indonesia with Indonesian sounds. Those sounds are a vowel sound /æ/ and six consonants $/ \mathrm{kj} /, / \mathrm{t} \mathrm{J} / / \mathrm{d} /, / \mathrm{d} z /$ and $/ 3 /$. As the result, the subjects substitute those sounds with the closest sounds available in Indonesian. In the data we could see that the subjects substituted the sound /æ/ with the sound /a/ or /e/ in apple, accurate, animal, ant and anniversary. The data (1), (2), (4), (5) and (6) showed that the subjects pronounced those words as: /'eipəl/ and /'apel/,/'ekurət/,/'anımol/,/ent/,/, eni'vz:səri/. Besides that, the subjects substituted the consonant cluster $/ \mathrm{kj} /$ with the single consonant $/ \mathrm{j} /$ in accurate. The data (2) showed that the subjects $3,4,6,8,9$, pronounced that word as: /'ekorət/. Next is the subjects has also substituted the consonant cluster $/ \mathrm{t} /$ with the single consonant /s/ and /c/ in achieve and challenge. The data (3) and (18) showed that the subjects $1,2,3,4,5,7$ and 8 pronounced achieve and challenge as : /o'si:v/ and /'celen/. They substituted the consonant /S/ with the consonant /s/ in crash, challenge, pushed, pressure and washing. The data (22), (53), (59), (61), and (64) showed that the 10

2012:1 -20 subjects 1,2,3,4,5,6,8 and 9 pronounced those words as: /kras/, /mu:'sisan/, /pus/, /'presər/ and /'wpsiy/. Moreover, they have substituted the consonant cluster $/ \mathrm{d}_{3} /$ with the consonant $/ \mathrm{j} /, / \mathrm{ch} /$ and $/ \mathrm{j} /$ in giraffe and huge. The data (42) and (46) showed that the subjects 1,2,3,4,5,6,7 and 8 pronounced those words as: /ji rafi/, /yu:ch/ and /yut/. The last is they substituted the consonant $/ 3 /$ with the consonant /s/ in camouflage, measure and revision. The data (20), (54) and (62) showed that all the subjects $1,2,3,4,5,6,7,8,9,10,11$ pronounced those words as: /'kamuflas/,/'mesur/ and /rı' fisen/.

The second error is the subjects substituted the English vowels into Indonesian vowel. Pronouncing the English vowel and consonant seemed to be the most difficult part for the students. Indonesian and English have different vowels. Indonesian has only five vowels, they are five letters that represent vowels in Indonesian "a, i, u, e, o," whereas in English there are fourteen vowels. Therefore, the subjects in this research made many errors in pronouncing the vowels. (a) The data (10) showed that the subjects substituted the vowel /i/ with the vowel /e/ in believe. 1, 2,3,4,7,6,11 pronounced the word as : /be'li:v/ instead of /bi'li:v/. (b) Substitute the vowel / $\mathrm{s} /$ with the vowel $/ \mathrm{a} /$ in called. The data (21) showed that the subjects 2,3,4,6,8,11 pronounced the word as: $/ \mathrm{ka}: \mathrm{ld} /$ instead of $/ \mathrm{ko:ld} /$. (c) Substitute the vowel $/(ə) /$ with the vowel $/ \mathrm{u} /$ in difficult. The data (32) showed that the subject 1, 2, 3, 6, 7 pronounced the word as /'difikult/ instead of /'difik(ə)1t/. (d) Substitute the vowel /3/ with Jurnal Ilmiah xxxxxxxxxxxx Vol.x No.x, April 
the vowel /i / in first. The data (37) showed that the subjects $1,4,5,7,9$ pronounced the word as /fi:rst/instead of /f3:rst/. (d) Substitute the vowel /u:/ with the vowel /o/ in goose. The data (43) showed that the subjects $3,9,7,8$ pronounced the word as /go:s/ instead of /gu:s/. (e) Substitute the second vowel /i/ with the vowel /e/ in increasingly. The data (52) showed that the subjects $1,2,5,6,9$ pronounced the word as /In'kre:sinli/ instead of /In'kri:sinli/.

The third error is word cognate cases. The subjects tended to pronounce the borrowed words from English like how they are in Indonesian. Based on data there are four words in English that the subjects pronounced used Indonesian version. We could see in the data (1) showed that the word "apple" is pronounced as /apél / in Indonesian, instead of /'æp1/ in English; the data (2) showed that the word "accurate" is pronounced as /aku-rat/ in Indonesian instead of /'ækjərət/ in English and the data (30) showed that the word "data" is pronounced as /data/ in Indonesian instead of /'dertə/ in English.

The fourth is language interference. Language interference is the effect of native language pronunciation when two or more languages cross or overlap, it involves with accurate pronunciation or proper way of describing something. The sounds $/ \mathfrak{x}, \Lambda, 3, \mathrm{v}$, $\theta$, $\mathrm{d} /$ are the sounds that do not exist in Bahasa Indonesia. Therefore, most of the subjects found difficulties in pronouncing some words that contain those sounds, as the result of that the subject substitute the difficult sounds with the Indonesian sounds. Data (4), (5), (11), (15), (16) and data (62) showed that the word "animal, ant, bury, bought, brought, and revision," are pronounced as /'anımol/, /buri/, /buri/, /buri/, /brau:t/, and /ri'fisen/ instead of /'ænıml/, /ænt/, /beri/, /bo:t/, /bro:t/, and /ri'viz(ə)n/.

Pronouncing the silent consonant $/ \mathrm{h} /$ is also the other error that had been conducted by the subjects. The data (48) and (45) showed that the subjects pronounced the silent consonant / $\mathrm{h} /$ clearly; the word "honor" and "hour" are pronounced as /'honor/ and /'hawər/.

Deleting or omitting some consonants that appeared at the end of some words has also occurred in this analysis. The data (21), (27), (29) and (56) showed that the subjects deleted or omitted some consonants at the end of the words. The subject deleted the consonant /d/ in / ks:1/ (21), consonant /t/ in /kukt/ (27), consonant/d/ in /di'vsI/ (29) and $/ \mathrm{pleI} /$.

The subjects pronounced the silent consonant $/ t /$ in the word "often". The data (63) showed that the subjects 1, $2,3,4,5,6,7,8,9,10$ and 11 pronounced the word often as /'s:ftən/. The subjects pronounced the silent consonant/t/ clearly.

The subjects added the consonant $/ \mathrm{r} /$ at the word that word doesn't required the consonant $/ \mathrm{r} /$. The data (65) showed that the subjects $1,5,8$ pronounced the word wonderful as /'wındərfol/ instead of /'wAndəful/.

The last error is some subjects seemed to generalize the pronunciation of the 
past tense morpheme which is ended by a bound morpheme /ed/. Indonesian does not have a word form. Moreover, all the words in Indonesian are pronounced as they are in the form of writing, which is of course different from English. English has phonetic spelling that is irregular and arbitrary, which makes it difficult for the subjects to recite. Therefore the subjects generalized to pronounce one word to another word. For example the data (9), (21), (27), (28), (56), (59) showed how the subjects pronounced the regular pasttense morpheme /ed/ in the words "baked, called, cooked, climbed, played, pushed" as “/beked/, /ks:ldid/, /kuked/, /klembid/,/pleyid/, /pushed/." Is seems like the subjects thought that all the regular pasttense morpheme /ed/ should be aspirated pronounce.

Next are some causes of students' pronunciation error made in speaking English. There are three causes of error pronunciation made by the subjects. The first is an interference error, based on the interview data, the subjects made a lot of errors in pronouncing the English words, because the influence of their mother tongues and the first language acquisitions. The subjects' dialects and accents interrupt the subjects' English pronunciation. As we know that, all of the native languages and Indonesian words are spelled phonetically, it is different with the English words. English has various kinds of spelling for only one word. Therefore it created some problems in learning the inconsistent English spelling. The data showed that subjects' interferences 12 2012:1 -20 are the effect of native language pronunciation when two or more languages cross or overlap. It involves with accurate pronunciation or proper way of describing something. For example the data (4), (5), (11), (15), (16) and data (62) showed that the word "animal, ant, bury, bought, brought, and revision," are pronounced as /'anımol/, /buri/, /buri/, /buri/, /brau:t/, and /ri'fisen/ instead of /'ænıml/, /ænt/, /beri/, /bo:t/, /bro:t/, and /ri'viz(ə)n/. The errors happened because most of the subjects said that they found difficulties in pronouncing some words that contain the sounds $/ æ, \Lambda, 3, \mathrm{v}, \theta, \mathrm{\delta} /$, because the sounds do not exist in Indonesian and their native languages.

The second cause of pronunciation errors in English is an intra-language error. This is reflected in the characteristics of students who lack the rules of English. The error is because the subjects are worried about making mistakes when saying certain words, they feel embarrassed in saying these words, they become afraid that they will be laughed at and afraid of being criticized by the lecturer. Therefore, almost the majority of subjects make mistakes due to generalization. For example the data (9), (21), (27), (28), (56), (59) showed how the subjects pronounced the regular past-tense morpheme /ed/ in the words "baked, called, cooked, climbed, played, pushed" as “/beked/, /ks:ldid/, /kuked/, /klembid/,/pleyid/, /pushed/." Is seems like the subjects thought that all the regular past-tense morpheme /ed/ should be aspirated pronounce.

Jurnal Ilmiah xxxxxxxxxxxx Vol.x No.x, April 
The third caused was developmental error. The developmental errors were due to the subjects' English knowledge. It happens because the subjects have the limited knowledge of vocabulary. As the result the subjects sometimes over generalize in pronouncing the words. As we could see in the data (9), (21), (27), (28), (56), (59) almost the subjects made the generalization that the entire regular past tense verb which ended with morpheme /ed/ should be pronounced.

\section{CONCLUSION}

Based on the result of the research and the data analysis, there are the types of pronunciation errors made by the subjects. The first is substituting the sounds that do not exist in Indonesian. The second error is substituting the English vowels into Indonesian vowel. The third error is pronouncing the English vowel and consonant. The fourth is cognate words error, it occurred because the subjects tended to pronounce the borrowed words from English like how they are in Indonesian. The fifth error is the effect of native language pronunciation when two or more languages cross or overlap. The seventh error is deleting or omitting some consonants that appeared at the end of some words has also occurred in this analysis. The subjects pronounced the silent consonant $/ t /$ in the word "often". The eight error is the subjects added the consonant $/ \mathrm{r} /$ at the word, that word doesn't required the consonant $/ \mathrm{r} /$ and the last error they seemed to generalize the pronunciation of the past tense morpheme which is ended by a bound morpheme /ed/.

Based on the interview there are three causes of error pronunciation made by the subjects. The first cause is the interference of the subjects' mother tongue. The second cause of pronunciation errors in English is an intra-language error. The third cause was developmental error. The developmental errors are due to the subjects' English knowledge.

\section{REFERENCES}

Alan, E. (1983). Oxford Learner's Pocket Dictionary. New York : Oxford University Press.

Armington, S. (Winter 1993/1994). Teaching Pronunciation at the micro level: Using keywords from students speech. TESOL Journal, 3 (2), 27 - 30.

Brown, H. D. (1980). Principles of Language Learning and Teaching. New Jersey. Prentice - Hall Inc.

Brown, H. D. (2000). Principles of Language Learning and Teaching (4th ed.). Longman: Sanfrancisco State University.

Carter, R., \& Nunan, D. (2001). The Cambridge Guide to Teaching English to Speakers of Other Languages. Cambridge: Cambridge University Press.

Corder, S. P. (1979). Idiosyncartic dialects and error analysis. In Dietrich Nehls. Studies in contrastive linguistics and error analysis: The theoretical 
background. Heidelberg: Julius Gross

Verlag Heidelberg.

Dalton, C. \& Seidlhofer, B. (1994).

Pronunciation. Oxford: Oxford

University Press.

Dulay, Heidi, Burt, M \& Krashen, S. (1982).

Language Two. New York : Oxfford

University Press.

Haycraft, B. (1987). Trial and Error. English

Teaching FORUM. 25. (3), 8- 11.

Ladefoged, P. (2001). A Course in Phonetics,

4th ed., Heinle and Heinle. Los

Angles: University of California.

Lenggo, N. (1995). What is an error? English

Teaching FORUM, 33 (3), 20 -24.

MacCharthy, P. (1978). The Teaching of

Pronunciation. Cambridge: Cambridge

University Press.
Morley, J. (1991a). Intensioe consonant pronunciation practice. Ann Arbor, MI: The University of Michigan Press.

Nunan, D. (2001). Second Language Teaching and Learning. Boston Heinie \& Heinie Publishers.

Nunan, D. (2003). Practical English Language Teaching. New York: Mc Graw Hall.

Pica, T. (1984). Pronunciation activities with an accent on communication. English Teaching FORUM, 22 (3), 2-6.

Richard, J. C (ed). (1974). Error Analysis : Perpective in Second Langauge Acquisition. Longman. 